\title{
REMEMBERING FEAR. THE FEAR OF VIOLENCE AND THE VIOLENCE OF FEAR IN SEVENTEENTH-CENTURY WAR MEMORIES
}

\author{
Andreas Bähr
}

In the summer of 1634 murdering and plundering Swedish troops threatened the Catholic Dominican convent Zum Heiligen Grab near Bamberg. On 19 August, however, as we learn from the nun Maria Anna Junius, 'the Swedish military that had been deployed across this area moved on in great haste and fear to Schweinfurt'. The chronicler was amazed by this sudden decampment, 'since at that time, not a single one of the Emperor's soldiers was around'. She could explain these happenings only as an act of God: 'I believe, our Lord has struck them with fear and driven them away'. Let us now move to Vienna, 1683. For two months, the city had been 'frightened' by the 'Turks'. ${ }^{2}$ Yet contemporary observers recount how, when the allied relief troops arrived at Vienna, the Ottoman forces, who had been so terrifying before, suddenly took fright and fled from their positions. Again, the victors felt 'astonishment'; the enemy had taken flight even though its military situation had been far from precarious. Authors could explain this behaviour only as the result of divine intervention. According to numerous broadsheets and eyewitness accounts, God had 'put a hare into the Turks' breast' and fear into their heart; He had 'struck' them with a 'blindness' that not only prevented people from recognising

\footnotetext{
1 Maria Anna Junius, 'Verzeignuß', published in 'Bamberg im Schweden-Kriege', ed. Friedrich Karl Hümmer, Bericht des Historischen Vereins für die Pflege der Geschichte des ehemaligen Fürstbistums Bamberg $5^{2}$ (1890), 1-168, and 53 (1891), 169-230, there 207 [my translation]. On Junius cf. Geoff Mortimer, Eyewitness accounts of the Thirty Years War 1618-48 (Basingstoke, Hampshire and New York: Palgrave, 2002), 97-111; Charlotte Woodford, Nuns as historians in early modern Germany (Oxford: Clarendon Press, 2002), esp. 117-143; Eva Kormann, Ich, Welt und Gott. Autobiographik im 17. Jahrhundert, Selbstzeugnisse der Neuzeit 13 (Cologne, Weimar and Vienna: Böhlau, 2004), chpt. II.B.1.

${ }^{2}$ For references see n. 13 .
} 
God but also blinded them to their own advantage. ${ }^{3}$ According to natural philosophers, such blindness resulted from fear, anxiety and terror. By striking them with blindness, God had thus also struck them with fear.

These 'scourges' of fear must not be regarded as mere metaphors. In the seventeenth century, fear and anxiety were perceived to be physically violent; that is, they were 'affects' in the historical sense of the word: they 'affected' the body and caused it to move- both externally as well as internally. The fear of violence sent by God might result not only in flight but also in deadly illness or sudden death. It was not until the late eighteenth century that we can observe the epistemological shift that remains influential today. In Enlightenment thought, 'affects' were transformed into 'feelings' and confined within the closed and inaccessible inner space of the person. ${ }^{4}$ We can find significant differences between spatial concepts of fear and anxiety in the early modern period and their psychological conceptualisations since the late eighteenth century. Fear could be perceived as physically powerful and violent because the inner space of the person did not qualitatively differ from external space.

In the Thirty Years War and the wars against the 'Turks', autobiographers, diarists and chroniclers recalled not only the physical violence they

3 Johann Peter von Vaelckeren, Wienn von Türcken belägert/von Christen entsezt ... (Linz, 1684), 92; Summarische Relation/ Was sich in währender Belägerung der Stadt Wien inund ausser deroselben zwischen dem Feind und Belägerten von Tag zu Tag zugetragen.... (Nuremberg, s.a.), 12; Eberhard Werner Happel, Der Ungarische Kriegs-Roman, Oder Außführliche Beschreibung/Deß jüngsten Türcken-Kriegs ... (Ulm, 1685), 812.

4 On the concept of 'affect' see e.g. Justus Georg Schottelius, Ethica. Die Sittenkunst oder Wollebenskunst, ed. Jörg Jochen Berns (reprint of the Wolfenbüttel edition, 1669; Bern and Munich: Francke, 1980), 109. 'Passion' and, in rare cases, 'emotion' (literally meaning the bodily 'motion' of vital spirits, humours, the senses, and the soul) could be used synonymously with 'affect'. See 'Affectus', in Johann Heinrich Zedler (ed.), Grosses vollständiges Universal Lexicon aller Wissenschafften und Künste (Halle an der Saale and Leipzig, 17321754), vol. 1, col. 718; 'Emotion', in Jacob and Wilhelm Grimm (eds.), Deutsches Wörterbuch. Neubearbeitung (Leipzig and Stuttgart: Hirzel, 1983-), vol. 7, col. 1253; 'Passion', in Ephraim Chambers (ed.), Cyclopcedia: or, an universal dictionary of arts and sciences ... (London, 1728), vol. 2, 759-762, there 760-761; Michel de Montaigne, Les Essais, ed. Jean Balsamo, Bibliothèque de la Pléiade 14 (Paris: Gallimard, 2007), bk. 2, chpt. 11, 445, 447; Jacques Chaillou, Traité du mouvement des humeurs, dans les plus ordinaires émotions des hommes (Paris, 1680). Cf. Dominik Perler, Transformationen der Gefühle. Philosophische Emotionstheorien 1270-1650 (Frankfurt am Main: Fischer, 2011), 24; Catherine Newmark, PassionAffekt-Gefühl. Philosophische Theorien der Emotionen zwischen Aristoteles und Kant, Paradeigmata 29 (Hamburg: Meiner, 2008), 9-10; Barbara H. Rosenwein, 'Emotion Words', in Piroska Nagy, Damien Boquet (eds.), Le sujet des émotions au Moyen Âge (Paris: Beauchesne, 2008), 93-106. On the modern concepts of 'feeling' (Gefühl) and 'emotion' cf. Ute Frevert, 'Gefühle definieren. Begriffe und Debatten aus drei Jahrhunderten', in Ute Frevert et al., Gefühlswissen. Eine lexikalische Spurensuche in der Moderne (Frankfurt am Main, New York: Campus, 2011), 9-39, there 24-31. On the spatiality of 'feeling' cf. Monique Scheer, 'Topografien des Gefühls', in Frevert, Gefühlswissen, 41-64. 
had suffered but first and foremost the fear of this violence. I will argue that in order to understand the historical function of these war memories, we need to historicise the language of fear and anxiety as well as concepts of selfhood and the person. First, that involves analysing seventeenthcentury notions of the nature, causes and effects of fear and its religious and moral associations. Secondly, we have to examine why people wrote about fear. It is not my objective to establish whether authors were 'actually' experiencing fear and anxiety or succeeded in 'coping' psychologically with emotional distress (such as historians of mentalities do when applying modern concepts of feeling). Rather, I analyse the functions of describing these affects. ${ }^{5}$ Those who wrote about fear and anxiety, be it their own fear or that of others, positioned themselves as fearless and Godfearing believers. They recalled the violent fear of a violence past in order to prove that, in the here and now, they had overcome their fear as well as to exemplify the conditions for combating fear effectively. In doing so, they not only remembered destructive fears from the past but also urged their readers to experience the right fear in the future: that is, the fear of God. Time and again, authors of seventeenth-century German war memoirs underlined the 'indescribability' and 'ineffability' of what they had suffered. In doing so, however, they did not remain silent but paradoxically were moved to describe their earlier experiences. They considered it necessary to recount in detail their sufferings. In providential thought, it was only through remembering fear that life could be lived without fear.

In the seventeenth century, fear of violence appeared to many to be more terrifying than the violence that was feared. ${ }^{6}$ How can this phenomenon

${ }^{5}$ For a psychohistorical approach towards the history of early modern fear and anxiety see in particular Jean Delumeau, La peur en Occident (XIV ${ }^{e}-X V I I I{ }^{e}$ siècles). Une cité assiégée (Paris: Fayard, 1978) and his Sin and Fear. The Emergence of a Western Guilt Culture, 13th18th Centuries (1983, New York: St. Martin's Press, 1990). Recent research offers criticism of Delumeau's empirical results but not of his psychological categories: William G. Naphy and Penny Roberts (eds.), Fear in early modern society (Manchester and New York: Manchester University Press, 1997); Anne Scott and Cynthia Kosso (eds.), Fear and its representations in the Middle Ages and Renaissance, Arizona Studies in the Middle Ages and the Renaissance 6 (Turnhout: Brepols, 2002); on the nineteenth and twentieth centuries cf. Joanna Bourke, Fear. A cultural history (London: Virago, 2005).

${ }^{6}$ Johann Heinrich Alsted, Encyclopcedia Septem tomis distincta (Herborn, 1630), 2369, tacitly quoting from Laelius Peregrinus, De noscendis et emendandis animi affectionibvs [1603] (Leipzig, 1714), 190-191; Schottelius, Ethica, 224; Christoph Lehmann, Florilegium Politicum. Politischer Blumen Garten, ed. Wolfgang Mieder, Nachdrucke deutscher Literatur 
be explained? As many authors told their readers, fear and anxiety were able to affect not only the imagination but also the physical world. A timorous and fearful imagination seemed capable on its own of bringing about the very things and events it dreaded. Physicians in particular gave many examples of such occurrences. Almost every tract on epidemics pointed out that to timorously imagine the plague might cause the malady. When trying to explain this mechanism, physiologists referred to humours and vital spirits, firstly, to an oppression of the heart, and secondly, to the power of imagination which was thought to be able to cause those things it imagined and signified. ${ }^{7}$ This power of imagination became particularly relevant when it was affected by fear since fear was considered to be the necessary precondition for the salvation of souls.

Accordingly, physiological explanations were closely associated with theological ones. Plague was often explicitly described as an act of 'divine violence'. ${ }^{8}$ When sending the plague God punished the sinners and tried and tested the pious; eternal damnation awaited those who, even when suffering this scourge, refused to repent and do penance. Only those who trusted in God's merciful protection were safe from the plague; they knew that God sent the plague as punishment and affliction and that God would be merciful to those who were aware of and accepted this fact. In other words: only those with the right kind of fear would prove to be safe. Only those who tried to change their lives when the plague was approaching would be safe; that is, only those who were afraid of the sin for which the plague was sent as punishment. Those who feared the plague, however, would be taken ill; that is those who were not afraid of the root of

des 17. Jahrhunderts 61 (Reprint of the 1639 edition, Bern, Frankfurt am Main and New York: Lang, 1986), 227, cf. also 224. For examples from the sixteenth century see esp. Montaigne, Essais, bk. 1, chpt. 17, 78: 'C'est ce dequoy j'ay le plus de peur que la peur. Aussi surmonte elle en aigreur tous autres accidents.' 'What I am mostly afraid of is fear. Its violence exceeds any other harm' [my translation].

7 See esp. Johann Werfring, Der Ursprung der Pestilenz. Zur Ätiologie der Pest im loimographischen Diskurs der frühen Neuzeit, Medizin, Kultur und Gesellschaft 2 (2nd ed., Vienna: Ed. Praesens, 1999), 174-222.

8 Johann Wilhelm Mannagetta, Pest-Ordnung...(s.l., 1681), 2. Cf. also Athanasius Kircher SJ, Natürliche und Medicinalische Durchgründung Der laidigen ansteckenden Sucht/ und so genanten Pestilentz... (Augsburg, 1680), 80, 130; Kurtzer/ doch Gründlicher Nach- und Vnterricht/ Wie man sich/nechst Göttlicher Hülffe und Beystand/ bey diesen jetzt besorglichen Zeiten/ in welchen ... die Pestilentzische Fieber und Peste/ in den benachbarten Ländern sich grausam verspüren lassen/von Zeiten zu Zeiten sich ziemlich ausbreiten/ und näher zu unsern Grentzen schleichen/vor solche gifftig-boßhafft anstekkende Krankheiten bester massen prceserviren/schützen/ und bewahren könne... (Brunswick, 1680). 
the punishment but of the punishment itself. ${ }^{9}$ Plague would strike those who relied on their own strengths to avoid falling ill, for instance by using 'magical' devices or by acting without the filial fear of God. Indeed, in the face of its physical effects and its religious causes, fear itself attained the character of a punishment; thus, many contemporaries perceived the fear of the plague to be more damaging than the actual disease. ${ }^{10}$

During the wars of the 'iron century', including the Thirty Years War and the fights against the Turks, not only the fear of the plague but also the fear of military violence had its own violent, sometimes even deadly, consequences. The fear of murderous soldiers, be they Protestants, Catholics or Muslims, or the troops of Gustav Adolf, the Emperor or Grand Vizier Kara Mustafa, produced various physical and psychological illnesses; such fear resulted in life-threatening fevers, premature births and miscarriages or could even be a direct cause of death. Many autobiographical texts tell us that those suffering from this fear might lose their minds, the integrity of their person and finally themselves. Authors like the Augustinian nun Clara Staiger were afraid of the deadly violence of the 'great anxieties of death' because such anxieties, especially when leading to a sudden and unprepared death, endangered not only the body but also the soul and thus appeared to be a 'well-deserved divine punishment'. In a sense, authors like Staiger were afraid of feeling fear. ${ }^{11}$

Balthasar Kleinschroth, secular priest and prefect of the singing school in the Cistercian Abbey of the Holy Cross in the Vienna Woods, provides another example of this phenomenon. As he tells us in his diary (1686), he had to 'pay with his skin' for the 'terror and the serious worries' that he had endured during the siege of Vienna in 1683: he was suffering from

9 Theophrastus Paracelsus, 'De pestilitate', in Paracelsus, Werke, ed. Will-Erich Peuckert, 5 vols. (2nd ed., Basel and Stuttgart: Schwabe, 1982), vol. 5, 176-261, there 240-241.

10 Mannagetta, Pest-Ordnung, 32-34; see also 19-20; Johann Quistorp, Quatuor Novissima Oder fünff vnd funfftzig Predigten/ darin die männiglich hochnötig zu wissende Lehre Vom Tod vnd Abesterben/Von dem künfftigen algemeinen Gericht/ Von der Hellen vnd Hellen Pein/Von dem Ewigen Leben vnd Himmels Frewde/verhandelt wird. Neben angehengten sechßzehen Predigten von der Pestilentz (Rostock, 1629), 485-486; Georg Daniel Coschwitz and Christian Sigismund Finger, Timoris et terroris in peste noxa (Halle an der Saale and Magdeburg, 1722), 3.

11 Clara Staiger, 'Verzaichnus', in Klara Staigers Tagebuch. Aufzeichnungen während des Dreißigjährigen Krieges im Kloster Mariastein bei Eichstätt, ed. Ortrun Fina (Regensburg: Pustet, 1981), ff. 80-81, 357; Junius, Verzeignuß, 29, 34, 57-58, 74, 156; 'Aufzeichnungen des Pfarrers Plebanus von Miehlen aus den Jahren 1636/37', ed. Ferdinand Heymach, Nassauische Annalen 38 (1908), 255-285, there 281. Cf. Schottelius, Ethica, 221. On Staiger cf. Mortimer, Eyewitness Accounts, 96-111, 180-181; Woodford, Nuns, esp. 106-116, 125-143; Kormann, Ich, Welt und Gott, chpt. II.B.2. 
attritis or glidersucht. Kleinschroth tried various medical therapies, both against the consequences of the 'ingested terror' and against the terror itself, but these therapies did not get at the cause of the problem. ${ }^{12}$ It was not until the 'Turkish threat' had been overcome that Kleinschroth got a real chance to recover:

These days [shortly after September 12, 1683], we heard the joyous news, that last Sunday the city of Vienna had been happily relieved. Immediately, the Patres reminded me that on this day I had been delightfully relieved of my own besiegement, that is, in my own words, that I was no longer confined to bed.

Kleinschroth plays on words: he associates the German word 'Belagerung' (besiegement) with 'Bettlagerung' (confinement in bed). But this construction was not merely a pun. The analogy of the patient's 'anxiety' with the 'anxiousness' of the besieged city ${ }^{13}$ was considered to be not only lin-

12 Balthasar Kleinschroth, Flucht und Zuefluchts Eigentliche und Wahrhaffte beschreibung, welche sich zuegetragen in der Türckhischen und Tarterischen Landesverwiestung in Österreich Anno 1683 ... (Stiftsarchiv Heiligenkreuz, Rubr. 3/Fasc. V), ff. 204r-216v, 251v, 281r, 29or (the quotations are on ff. $251 \mathrm{v}$ and 281r). The text is cited below as Flucht und Zueflucht. Two-thirds of the manuscript have been edited by P. Hermann Watzl S.O. Cist. as Flucht und Zuflucht. Das Tagebuch des Priesters Balthasar Kleinschroth aus dem Türkenjahr 1683, Forschungen zur Landeskunde von Niederösterreich 8 (2nd ed., Graz and Cologne: Böhlau, 1983) (cited below as Tagebuch); see 179-183.

13 For the 'anxiousness' of the city (and not only of its inhabitants) see Christoph Fürer von Haimendorf, Die bekriegte/ und triumphirende Donau in Londen eingeführt und vorgestellt/ Als des Kayserlichen Herrn Abgesandtens in Engelland etc. Hrn. Grafen von Thun Excellentz alldorten die Nachricht erhalten/Vber Den Entsatz Der Von TVrCken/VIeL geängstIgten StaDt VVIen (Nuremberg, 1683); Georg Christoph von Kunitz, Diarium Welches Der am Türckischen Hoff / und hernach beym Groß-Vezier in der Wienerischen Belägerung gewester Kayserl. Resident Herr Baron Kunitz eigenhändig beschrieben ... (s.l., 1684), f. B ir; Johann Ferdinand Fischer, Diarium, Oder Weitläuffig und gründliche Beschreibung/ von der Käys. Haupt- und Residentz-Stadt Wien/ In Unter-Oesterreich/ im Viertel unterm Wiennerwald liegend; welche vom 14. Julij/ biß 12. Septemb. Anno 1683. 61. Tag von des Türckischen Käysers Sultan Machomet Kriegs-Volck ... ist belägert worden ... (Regensburg, s.a.), [10]; Vaelckeren, Wienn, 94, cf. also 88; Happel, Der Ungarische Kriegs-Roman, 658, 772; Christian Wilhelm Huhn, Nichts Neues und Nichts Altes/ oder umbständliche Beschreibung, Was Anno 1683. Vor/ bey und in der Denckwürdigen Türckischen Belagerung Wien, vom 7 Julii biß 12 Septembr. täglich vorgelauffen ... (Breslau, 1717), 70-71, cited in Walter Sturminger, Die Türken vor Wien in Augenzeugenberichten (Munich: dtv, 1983), 135; Johann Martin Lerch, Warhaffte Erzehlung: Welcher gestalt in der ängstlichen Türckischen Belägerung der Käyserlichen Haupt- und Residentz-Stadt Wien in Oesterreich Durch das feindliche Lager gedrungen/ und die erste Kundtschafft zur Käyserlichen Haupt Armada, wie auch von dar glücklich wieder zuruck gebracht worden (s.l., 1683), f. 3r, cf. f. 1v. Cf. also Erasmus Francisci, Schau- und Ehren-Platz Christlicher Tapfferkeit/ Das ist: Aller Denck- und Ruhmwürdig ausgestandenen Belägerungen der Weltberühmten Römisch-Käyserlichen Ansitz-Stadt Wien in Oesterreich... (Nuremberg, 1684), 1-4, esp. 3. M.M.S., Ausführ- und gründliche Erzählung dessen/was sich vor würklicher Belagerung der Käiserlichen Haupt- und Residenz-Stadt 
guistic but also causal. ${ }^{14}$ As indicated by its etymology, the word 'anxiety' was used to describe the feeling of being confined and oppressed in an affective sense but referred as well to the spatial, physical impact of this affect. ${ }^{15}$

Neither Kleinschroth nor the city of Vienna was relieved of their dangerous anxieties and besiegement until God put their enemies to flight. As numerous eyewitnesses tell us, He did so by terrifying the 'Turks' with the fearlessness of the Christian soldiers trusting in His merciful protection; that is, by leading the Ottoman forces to military defeat and making them aware of His might. ${ }^{16}$ God tried the pious, and He made sinners afraid of those fearless believers who had overcome the temptation to give in to fear. This mechanism is also impressively manifest in the autobiography of the Jesuit polymath Athanasius Kircher (1602-1680). The Vita is believed to have been written in the late 1660 s and was posthumously discovered and published by his confreres in the Collegium Romanum in Rome, where Kircher had lived since 1633, after fleeing the atrocities of the Thirty Years War. ${ }^{17}$

Wienn in Oesterreich/ im Jahr Christi M. DC. LXXXIII. zugetragen (Nuremberg, 1684), 63, characterises Vienna as a 'dungeon of anxiety'.

14 Kleinschroth, Flucht und Zueflucht, f. 214r, cf. also f. 206v; Tagebuch, 182 [my translations]. For further details and bibliographical references see Andreas Bähr, Furcht und Furchtlosigkeit. Göttliche Gewalt und Selbstkonstitution im 17. Jahrhundert, Berliner Mittelalter- und Frühneuzeitforschung 14 (Göttingen: V\&R unipress, 2013), chpt. 5·3.

15 See 'Angst', in Zedler (ed.), Universal Lexicon, vol. 2, cols. 301-304, there 301, 304; Michael Stolberg, "'Zorn, Wein und Weiber verderben unsere Leiber". Affekt und Krankheit in der Frühen Neuzeit', in Johann Anselm Steiger (ed.), Passion, Affekt und Leidenschaft in der Frühen Neuzeit, Wolfenbütteler Arbeiten zur Barockforschung 43 (Wiesbaden: Harrassowitz, 2005), vol. 2, 1051-1077, there 1060-1061, 1072-1073; Hartmut Böhme, 'Vom phobos zur Angst. Zur Transformations- und Kulturgeschichte der Angst', in Martin Harbsmeier, Sebastian Möckel (eds.), Pathos, Affekt, Emotion. Transformationen der Antike (Frankfurt am Main: Suhrkamp, 2009), 154-184, there 168-169. On the early modern concept of 'anxiety' cf. also Hartmut Lehmann, "'Not, Angst und Pein". Zum Begriff der Angst in protestantischen Kirchenliedern des späten 16. und des frühen 17. Jahrhunderts', Zeitschrift für Kirchengeschichte 117 (2006), 297-310.

16 Georg Christoph von Kunitz, Diarium... Nebst außführlicher Relation Der Wienerischen Belägerung... (s.l., 1684), ff. A ir, A 3v-B ir.

${ }_{17}$ I quote here from John Fletcher's translation of the printed version (Vita Admodum Reverendi P. Athanasii Kircheri ..., annexed to Fasciculus epistolarum Adm. R.P. Athanasii Kircheri Soc. Jesu ..., ed. Hieronymus Ambrosius Langenmantel (Augsburg, 1684)): Athanasius Kircher SJ, Vita, in John Edward Fletcher, A study of the life and works of Athanasius Kircher, 'Germanus incredibilis'. With a selection of his unpublished correspondence and an 
In 1623 , as Kircher tells us, when he was on his way to the theological college of the Society of Jesus in the Saxonian city of Heiligenstadt, he had a remarkable 'misadventure'. Although Kircher 'had to pass through many places occupied by non-Catholics', he did not pay heed to those well-meaning colleagues and friends who urged him to conceal his affiliation to the Jesuit order while en route; he preferred to 'die dressed in my Order's habit than [to] travel unmolested in secular clothing'. ${ }^{18}$ In the 'wild' and 'horrid' 'Valley of Hell' (Höllental), Kircher did not have to wait very long for this threat to materialise. ${ }^{19}$ He was surrounded by Lutheran horsemen who were camped in the woods, duly recognised as a Jesuit, robbed, beaten and injured. What is more, since these 'brutal fellows' proved to be not only possessed by avarice but also by 'implacable hatred against Jesuits', they prepared to hang their victim and led Kircher to the tree they used for executions. ${ }^{20}$

Recognising his situation as hopeless, Kircher collected his thoughts, fell to his knees, raised his eyes to heaven 'and in tears recommended myself with immense fervour to God and the Mother of God'. Kircher prepared himself for martyrdom: 'I thanked [the] benevolent God for deeming me worthy to suffer death for the honour of His most holy name'. Tears poured from his eyes and produced a remarkable effect. As tears flowed out, consolation flowed in: 'All my terror had vanished and I felt the greatest readiness to surrender to God my life and body'. By being tearfully fearless, however, and in preparing composito animo for what he initially had been afraid of, Kircher was able to avert the threat. When one of the attackers saw the abundant tears of his victim, he was 'seized with [such] compassion' that he urged his fellow soldiers not to soil their hands with the blood of an innocent man. Jesuits were evil, no doubt, but

annotated translation of his autobiography, ed. Elizabeth Fletcher, Aries Book Series. Texts and Studies in Western Esotericism 12 (Leiden, Boston: Brill, 2011), 459-551, there 480-481. The manuscript is entitled Vita R.P. Athanasii Kircheri S.J. Romce in Collegio Romano post obitum eius inventa, ibidemque, agente R.P. Conrado Holtgreve, cum facultate R.P. Provincialis Romani 7. Sept. anno 1682 primùm, deinde iterum anno 1683 descripta Neuhusij à J.K. S.J. (Hochschul- und Landesbibliothek Fulda, Hs. $8^{\circ} \mathrm{B} 103$ ); the relevant passage is on $\mathrm{ff.}$ 22v-25r.-We do not know whether Kircher wrote his autobiography only for his confreres (as Ignatius of Loyola did when relating his own life story to Jerónimo Nadal) or if he was addressing the broader audience reached by the posthumous publication of the text.

18 The Fulda manuscript speaks of 'heretics' (loca hceretica): Vita R.P. Athanasii Kircheri, f. 23 r.

19 According to Kircher, the valley is situated between Eisenach and Marksuhl: Kircher, Vita, 480.

20 Ibid., 480. 
Kircher should not suffer for that. Whoever killed this man, the speaker proclaimed, would face divine punishment. Moved by their comrade's remonstrations, the other soldiers let Kircher go and returned his stolen goods. And what is more: 'seized by panic, they fled into the forest, leaving me alone with my clothes and the papers I had been carrying'. Kircher's saviour, however, came back alone in order to ask Kircher to intercede for him so that God might not find him guilty of the crime and to urge Kircher to leave this dangerous place. This time, the traveller took the advice and thanked the Almighty for mercifully protecting him-albeit 'lamenting ... that such an opportunity of dying for the honour of God had been taken from me'.21

Athanasius Kircher had been threatened with death; although terrified he overcame his fear, and in doing so terrified his attackers. At first, the soldiers' 'anxiety' (pavor) appears to be the terror of their conscience upon recognising their offence and its expected consequences. But how can it be explained that these soldiers not only listened to reason and let Kircher pass but also withdrew into the forest, filled with 'panic'? Why did Kircher's fearlessness have such a powerful impact? Again, the answer lies in the notion of providence. God punished the sinners by making them fear, and He made them fear by confronting them with the fearlessness of a God-fearing believer who was willing to suffer. Not only in eternity but also on earth, fearlessness dispelled fear by disposing of its rationale. No one who feared God need be fearful, and that sort of fearlessness might in turn terrify others into a fear of God. The soldier, who saved Kircher's life, admired and revered him because he recognised him as a man whom God had released from fear.

The soldier's change of heart appears to have resulted from religious and moral reflection not shared by his comrades who fled in 'panic'; that is, they took flight without being aware of the true nature of the dangers threatening them. In contrast to the qualms of conscience felt by Kircher's protector, this panic was considered an indication of mental and psychic disintegration, the same 'loss of reason' that Clara Staiger had already noted was more terrifying than the death of the body. ${ }^{22}$ Because Kircher was not afraid of dying, those threatening him with death became concerned about their souls. Yet instead of engaging in spiritual and moral self-examination, these soldiers fled from God's countenance. Their

21 Ibid., 480-481.

22 Staiger, 'Verzaichnus', ff. 80-81, cf. f. 357. 
panicked anxiety would not save them from the terrifying punishment that they sought to avoid. Such anxiety was not only a response to a warning of eternal sanctions: it was the very divine punishment which they dreaded. This fear mirrored the offence: Kircher's fearlessness struck fear into those who had previously made him afraid. In displaying such panic, these soldiers did not atone for their guilt but gave proof of it.

In these examples, those who were fearful or fearless do not appear to be acting subjects. According to his autobiography, Athanasius Kircher had by no means foreseen what would happen to him. The aggressors could be driven away by their victim because Kircher did not act to repel them himself but left his rescue up to God's benevolent power. Kircher prepared himself for martyrdom and even provoked it, and this decision made possible his survival because he refrained from taking action by 'himself. The same is true of those who got into a 'panic'. They did not act themselves but were violently 'seized', as Kircher puts it, or, to quote Maria Anna Junius, they were physically 'stricken and driven away'. ${ }^{23}$ It is not human subjects, who are acting here but their affects, and this implies that it is really God who is at work. ${ }^{24}$ What becomes manifest here is a specific early modern concept of the acting person.

In Kircher's depiction of the scene there are various elements flowing in and out: tears and consolations, blood and life. This process appears to be a physical one and thus, it has a specific spatial structure. It was in this space that fear and fearlessness attained their violent power. In the seventeenth century, the inner space of the person did not qualitatively differ from his outer world, and the space of affects did not differ from the space of action. To put it differently: the elements of the world and human and divine occurrences were considered to be closely connected by semiotic and causal interrelations, by relations of analogy and similarity. The 'person' causing fear and being 'filled' with fear was not yet conceptualised as an individual self, psycho-physically closed, but as both a medium and an arena of the cosmic battle between good and evil. ${ }^{25}$

23 Junius, Verzeignuß, 207.

24 Cf. Böhme, 'Vom phobos zur Angst', 163.

25 On early modern concepts of person see Michel Foucault, The order of things. An archaeology of the human sciences (1966, London and New York: Routledge, 2002); Clifford Geertz, "From the native's point of view". On the nature of anthropological understanding', in Janet L. Dolgin, David S. Kemnitzer and David Murray Schneider (eds.), Symbolic anthropology. A reader in the study of symbols and meanings (New York: Columbia University Press, 1977), 480-492, there 483; Ralf Konersmann, Kulturelle Tatsachen (Frankfurt am Main: Suhrkamp, 2006), 188; Claudia Benthien, Skin. On the cultural border between self 
It was not until the late eighteenth century that 'feelings' were regarded as invisible to the eye and unrepresentable by language, that the horde of spirits started being driven out of the world of nature and men, and that the soul was psychologised. Only in the Enlightenment was the interiority of the 'subject' imagined as an inaccessible space clearly separate from the space of exanimate 'objects'. In Enlightenment thought, fear and fearlessness lost their violent power.

When historicising early modern memories of fear we have to analyse not only the historical notions but also the functions of 'fear' and 'anxiety': we have to ask not only what people wrote about fear but also why they did so. Not only Catholic authors like Junius, Staiger, Kleinschroth and Kircher but also many Protestants described their own fear as being an earlier condition: those telling us that they had been frightened in the past and that their anxieties had been an act of divine violence introduced themselves as being 'converted' into their present state of fearless and God-fearing believers. ${ }^{26}$ Anyone able to talk about the fear of violence and the violence of fear already seemed to have defeated and overcome both. Fear and fearlessness operated in conjunction; the power of fear and the possibilities of disempowering it were mutually constituent. This is true, regardless of whether these authors wrote their diaries comparatively shortly after the relevant events or composed their autobiographies at the end of their lives, using, as Kircher did, various literary templates from hagiography and martyrologies. What is more, the religious epistemology underlying these narratives cannot be found only in war memoirs written by clerics or nuns but also in those written by laymen, e.g., in the autobiography of the Calvinist tradesman Augustin Güntzer. ${ }^{27}$

and the world (1999, New York: Columbia University Press, 2002). The spatial implications of these concepts of person become particularly manifest in autobiographical depictions of divinatory dreaming which can also be found in Kircher, Vita, 13-14. See Andreas Bähr, 'Spaces of dreaming. Self-constitution in early modern dream narratives', in David Sabean and Malina Stefanovska (eds.), Space and self in early modern European cultures, UCLA Clark Memorial Library Series 18 (Toronto: Toronto University Press, 2012), 219-238.

26 See Bähr, Furcht, chpt. 5.2.

27 Augustin Güntzer, Kleines Biechlin von meinem gantzen Leben. Die Autobiographie eines Elsässer Kannengießers aus dem 17. Jahrhundert, ed. Fabian Brändle and Dominik Sieber, Selbstzeugnisse der Neuzeit 8 (Cologne, Weimar and Vienna: Böhlau, 2002). 
We can thus conclude from historical depictions of fear that contemporaries held 'fear' and 'anxiety' to be crucial for processes of self-constitution and self-preservation. We should, however, not extend this understanding to conclude that the seventeenth century was an 'age of anxiety' in the psychohistorical sense of the term. Anyone trying to find out what people 'really' felt in the past is in the position of applying modern concepts of fear to historical and cultural contexts in which a psychological epistemology was unknown. For seventeenth-century authors 'fear' and 'anxiety', both their own and in others, were not interior mental experiences but rather a divine scourge.

Such a conceptualisation of fear and anxiety granted seventeenthcentury war memoirs functions very different from modern ones. Time and again, autobiographers and chroniclers articulated the desire to fall silent, ${ }^{28}$ and they underlined the 'ineffability' and 'indescribability' of their fear; however, in the end they decided to speak. They did not claim that individual suffering was inexpressible in itself but rather that no physical sheet of paper would prove large enough to record every single distressing event. It was a matter of quantity not quality. Thus, these authors did not try to forget but encouraged remembering (memoria). ${ }^{29}$ When recall-

28 E.g. 'Selbstbiographie des Stadtpfarrers Wolfgang Ammon von Marktbreit († 1634)', ed. Franz Hüttner, Archiv für Kulturgeschichte 1 (1903), 50-98, 214-239, 284-325, there 87; Sebastian Bürster, Beschreibung des schwedischen Krieges 1630-1647, ed. Friedrich von Weech (Leipzig: Hirzel, 1875), 87; Friedrich Hoppe, Johann Georg Mauls Diarium aus dem Dreißigjährigen Kriege (Naumburg an der Saale: Sieling, 1928), 7-8; Franz Martin, 'Das Hausbuch des Felix Guetrater 1596-1634', Mitteilungen der Gesellschaft für Salzburger Landeskunde 88/89 (1948/49), 1-50, there 34; Conrad Burger, 'Itinerarium', published as 'P. Konrad Burgers Reisebüchlein', ed. P. Gregor Müller, Cistercienser-Chronik 43-45 (1931-1933), vol. 43, 129 .

29 E.g. Junius, Verzeignuß, 154, 221; Bürster, Beschreibung, 1-2, 114; Gerd Zillhardt, Der Dreißigjährige Krieg in zeitgenössischer Darstellung. Hans Heberles 'Zeytregister' (1618-1672). Aufzeichnungen aus dem Ulmer Territorium. Ein Beitrag zu Geschichtsschreibung und Geschichtsverständnis der Unterschichten, Forschungen zur Geschichte der Stadt Ulm 13 (Ulm: Kohlhammer, 1975), 121, 159; Walter Kürschner, 'Aus dem Kirchenbuch von Reichensachsen (und Langenhain) von 1639-1653', Archiv für hessische Geschichte und Altertumskunde N.F. 9 (1913), 48-55, there 53; Burger, 'Itinerarium', vol. 43, 129; Gerhard Bätzing, 'Auszüge aus den ältesten Kirchenbüchern von Besse', Zeitschrift des Vereins für hessische Geschichte und Landeskunde 83 (1972), 97-135, there 124; G. Sello, 'Eine Potsdamische Pfarrchronik aus der Zeit des großen Krieges', Zeitschrift für preußische Geschichte und Landeskunde 20 (1883) (reprint 1973), 207-234, there 233; 'Aus den Predigten des Pfarrers Hartmann Kreid (1636-1650)', in Die Chroniken von Friedberg in der Wetterau, ed. Christian Waas, vol. 2 (Friedberg: Bindernagel, 1940), 1-25, there 13; Kircher, Vita, 483; Kleinschroth, Tagebuch, 91, 130, 195. For further details and bibliographical references see Bähr, Furcht, chpt. 5.2 and 5.3. On 'ineffability' as a rhetorical pathos formula cf. Claudia Benthien, 
ing their fear, they looked not only into the past but also into the future. They called on their readers to repent in order to prevent reoccurrence of past events; ${ }^{30}$ they sought to avert that divine punishment that no human being could escape without God's mercy and grace. ${ }^{31}$ In seventeenthcentury Germany, strategies for coping with fear as well as (the concept of) fear were shaped by religion. ${ }^{32}$ To overcome fear was therefore not a matter of individual well-being and therapeutic self-enhancement but rather a religious demand. In addition to being required to suffer from fear and anxiety in this world, Christians were also required to control these affects and to transform them into the righteous fear of God. Accordingly, writing about fear did not have the psychological objective of overcoming it; rather overcoming fear was a precondition for writing about it. Describing the fear of violence was not regarded and applied as an instrument for coping with 'psychic trauma' in the modern sense of the term. ${ }^{33}$ Those who remembered the war had survived (and that is why they were able to remember), but they wanted more than mere survival. When writing about their past fears they sought to religiously and morally preserve themselves for the future. In doing so, however, they did not describe themselves as autonomous, 'feeling' subjects. ${ }^{34}$ Those who recalled their fears effectively told their readers that they had already defeated these

Barockes Schweigen. Rhetorik und Performativität des Sprachlosen im 17. Jahrhundert (Munich: Fink, 2006).

30 This aspect has been neglected by Peter Sherlock, 'The reformation of memory in early modern Europe', in Susannah Radstone, Bill Schwarz (eds.), Memory. Histories, theories, debates (New York: Fordham University Press, 2010), 30-40.

31 Should the call go unheeded, a new war might break out. Tobias Wagner, for example, was convinced that after 1663 , God punished the Christians with the 'Turks' for having ignored the religious message of the Thirty Years War: Tobias Wagner, Türcken-Büchlein/ Das ist: Summarische Beschreibung deß Ottomanischen Hauses Herkommen/ und Kriegen/ biß auf gegenwärtige Zeiten ..., (2nd ed., Ulm, 1664), 219-220.

32 This is not to say that religion was (and is) caused by fear, as has been asserted by numerous historians and scholars of religion, drawing both on Enlightenment and ancient debates. See Bähr, Furcht, chpt. 2.2 and 2.3.

33 For a psychohistorical approach towards the history of the Thirty Years War cf. Bernd Roeck, 'Der Dreißigjährige Krieg und die Menschen im Reich. Überlegungen zu den Formen psychischer Krisenbewältigung in der ersten Hälfte des 17. Jahrhunderts' [1996], in Peter Claus Hartmann and Florian Schuller (eds.), Der Dreißigjährige Krieg. Facetten einer folgenreichen Epoche (Regensburg: Pustet, 2010), 146-157; Johannes Burkhardt, Der Dreißigjährige Krieg (Frankfurt am Main: Suhrkamp, 1992), 233-244.

34 On the concept of survival and its interrelation with 'trauma' and 'self-preservation' see Falko Schmieder, 'Überleben-Geschichte und Aktualität eines neuen Grundbegriffs', in Falko Schmieder (ed.), Überleben. Historische und aktuelle Konstellationen (Munich: Fink, 2011), 9-29. 
affects - by having knowledge of their violent impact and its causes and therefore being aware that fear and anxiety could not be defeated without the help of God's providence. Memories like these were associated not only with 'horror' but in some cases also with 'joy' - the grateful joy of having been relieved of a suffering that true Christians had to endure: the joy of having suffered, as a sign of salvation. ${ }^{35}$

35 Kleinschroth, Tagebuch, 44, 133, 146; Flucht und Zueflucht, f. 251v. Schottelius, Ethica, 179-180, speaks of 'joyous horror'. See also the chronicle of Johann Strahm from Ostheim near the Rhön (1657), published in Karl Zeitel, 'Die kirchlichen Urkunden im Kirchturmknopf der Michaeliskirche in Ostheim v. d. Rhön. Ein Blick in die Kirchen-, Schul- und Kulturgeschichte der Stadt Ostheim v. d. Rhön', Jahrbuch des Hennebergisch-Fränkischen Geschichtsvereins 19 (2004), 219-282, there 233-239, esp. 233 (f. 1r): 'Praeteritorum malorum recordatio jucundissima est. 'For a different interpretation of Strahm's account cf. Hans Medick, 'The Thirty Years War as experience and memory. Contemporary perceptions of a macro-historical event', in Lynne Tatlock (ed.), Enduring loss in early modern Germany. Cross disciplinary perspectives, Studies in Central European Histories 50 (Leiden and Boston: Brill, 2010), 25-49, esp. 35-36. 